\title{
EVALUASI ANALITIK POCT METODE GLUCOSE DEHYDROGENASE PARAMETER GLUKOSA PADA SPESIMEN SERUM DAN PLASMA EDTA
}

\author{
Suryanata Kesuma ${ }^{1}$, Didi Irwadi ${ }^{2}$, Nia Ardelia ${ }^{1}$ \\ ${ }^{1}$ Jurusan Teknologi Laboratorium Medis, Poltekkes Kemenkes Kaltim, Jalan Kurnia Makmur No.64, \\ Kota Samarinda, 75123 \\ ${ }^{2}$ RSUD Inche Abdoel Moeis, Jalan H.A.M Rifaddin No.1, Kota Samarinda, 75251 \\ E-mail: suryanatakesuma@gmail.com
}

\begin{abstract}
Diabetes mellitus is a non-communicable disease that can be prevented and detected as early as possible by routine glucose checks. Point Of Care Testing (POCT) is a screening tool for diabetes mellitus. These tools are widely used by health care institutions and even independently by the wider community. Blood glucose can be measured using serum, plasma, and whole blood specimens. The standard specimen for measuring blood glucose using the POCT tool is whole blood. Based on the author's survey, the use of the POCT tool in several health care institutions in Samarinda was not yet in accordance with the insert kit, one of which was the type of specimen used. Many laboratories use EDTA serum and plasma as specimens for glucose testing using the POCT tool. One method of measuring the POCT tool is the glucose dehydrogenase method. Therefore, analytic evaluation is necessary to ensure the precision and accuracy of laboratory examination results in blood glucose tests. This type of research is the analytical method with a comparative design. Data analysis using Microsoft Excel and SPSS applications. The number of samples for analytic evaluation was 40 samples. Based on the results of tests performed in duplicate, the values of precision (CV\%), accuracy (d\%), and Total Error (TE) were obtained from the results of glucose testing using serum and plasma EDTA samples, namely CV $3.3 \%$ and 3.5\% $d-9.8 \%$ and -15.8\%; and TE 16.4\% and 22.7\%, with a Total Error Allowable of 10\%, then there are clinical differences in glucose values using serum and plasma EDTA samples so that the use of these samples is not suitable for use for diagnostic purposes using the POCT glucose dehydrogenase method. There was a statistical difference in serum glucose and plasma EDTA against whole blood, which was examined using the POCT glucose dehydrogenase method with a correlation value $(R)$ of 0.9722 and 0.9695 .
\end{abstract}

Keywords : Precision, Accuracy, Total Error, POCT, Glucose

\section{PENDAHULUAN}

Diabetes merupakan salah satu penyakit yang menjadi ancaman serius bagi kesehatan dunia. Sekitar $90-95 \%$ dari kasus diabetes adalah Diabetes Melitus (DM) Tipe 2 yang disebabkan karena gaya hidup yang tidak sehat. International Diabetes Federation (IDF) Atlas 2017 melaporkan bahwa epidemi diabetes di Indonesia masih menunjukkan kecenderungan meningkat. Indonesia menduduki peringkat keenam dengan jumlah penderita diabetes dewasa tertinggi di dunia.
Berdasarkan data Riset Kesehatan Dasar (Riskesdas), estimasi jumlah penderita diabetes di Indonesia tahun 2018 lebih dari 16 juta jiwa. Peningkatan angka prevalensi cukup signifikan yaitu dari 6,9\% tahun 2013 menjadi 8,5\% di tahun 2018 (Kemenkes RI, 2018).

Pengendalian glukosa darah yang baik merupakan salah satu faktor penting dalam menurunkan risiko komplikasi pada penderita diabetes (Kemenkes RI, 2018). Peningkatan angka prevalensi penderita diabetes, mendorong adanya gagasan menggunakan alat 
Kesuma, S., dkk: Evaluasi Analitik POCT Metode Glucose Dehydrogenase Parameter Glukosa Pada Spesimen Serum dan Plasma EDTA

yang efektif mempercepat proses kontrol (Turn Around Time) dalam pelayanan pasien yaitu POCT (Point Of Care Testing) (Aulia, 2016). POCT dapat digunakan untuk memantau tingkat glukosa darah seseorang atau sebagai skrining tes diabetes. Ketika darah diteteskan pada strip, akan terjadi reaksi antara darah dan reagen yang ada di dalam strip dan dikonversi menjadi angka yang sesuai dengan jumlah muatan listrik sesuai dengan nilai zat yang diukur dalam darah (Keputusan Menteri Kesehatan Republik Indonesia, 2010). POCT sering digunakan di instalasi rawat inap, IGD (Instalasi Gawat Darurat), laboratorium, dan bahkan digunakan secara mandiri oleh masyarakat luas (Bishop et al., 2010).

Pada pemeriksaan glukosa darah, ada tiga metode enzimatik yang dapat digunakan, di antaranya glucose oxidase, glucose dehydrogenase, dan hexokinase (McPherson \& Pincus, 2011). Glukosa darah dapat diukur dengan spesimen serum, plasma, dan whole blood. Gold standard untuk tipe spesimen POCT adalah whole blood. Berdasarkan survei yang telah dilakukan oleh penulis, dari 10 institusi pelayanan meliputi tiga Rumah Sakit, dua Puskesmas, tiga Klinik dan dua Laboratorium Swasta, metode enzimatik POCT yang masih banyak digunakan adalah glucose oxidase dan lima diantaranya masih menggunakan spesimen serum dan plasma atau spesimen yang tidak sesuai dengan insert kit alat. Demikian juga dengan antikoagulan yang digunakan, gold standar untuk antikoagulan pemeriksaan glukosa darah adalah Natrium Fluorida (NaF), namun yang masih banyak digunakan adalah Ethylene Diamine Tetraacetic Acid (EDTA) pada POCT ataupun alat kimia.

Pada penelitian sebelumnya mengenai gambaran nilai glukosa darah metode GODPAP spesimen serum dan plasma EDTA, didapatkan hasil rata-rata $103,7 \mathrm{mg} / \mathrm{dl}$ untuk spesimen serum, dan rata-rata $101,3 \mathrm{mg} / \mathrm{dl}$ untuk spesimen plasma EDTA. Glukosa serum menunjukkan hasil yang lebih tinggi daripada glukosa plasma EDTA. Pada penelitian lain, perbandingan hasil pemeriksaan glukosa darah sewaktu pada spesimen whole blood dan plasma EDTA menggunakan POCT, didapatkan hasil dengan rata-rata $117,08 \mathrm{mg} / \mathrm{dl}$ untuk spesimen whole blood, dan rata-rata $150,38 \mathrm{mg} / \mathrm{dl}$ untuk spesimen plasma EDTA. Glukosa plasma EDTA menunjukkan hasil yang lebih tinggi daripada glukosa whole blood (Subiyono et al., 2016; Rosman, 2018).

Pentingnya pengetahuan dan pemahaman terkait SOP (Standar Operasional Prosedur) dan insert kit POCT untuk menjamin hasil pemeriksaan laboratorium. Penggunaan POCT tanpa pengetahuan yang baik, dapat menyebabkan kesalahan pengeluaran hasil (Widagdho, 2013). Berdasarkan hal tersebut, penulis melakukan uji pendahuluan dengan POCT terhadap nilai glukosa plasma EDTA, serum dan whole blood. Uji pendahuluan dilakukan dengan dua alat POCT yang berbeda merk namun menggunakan metode yang sama yaitu glucose oxidase dan diperoleh nilai yang meningkat secara berturut-turut. Mekanisme kerja enzim 
Kesuma, S., dkk: Evaluasi Analitik POCT Metode Glucose Dehydrogenase Parameter Glukosa Pada Spesimen Serum dan Plasma EDTA

glucose oxidase sangat bergantung pada keberadaan oksigen. Oleh karena itu, terdapat gagasan pergantian enzim glucose oxidase dengan enzim glucose dehydrogenase. Enzim glucose dehydrogenase dinilai lebih spesifik terhadap substrat glukosa dan aktivitasnya tidak dipengaruhi oleh nilai oksigen (Monosik et al., 2012).

Berdasarkan latar belakang di atas, evaluasi analitik perlu dilakukan untuk menjamin ketelitian dan ketepatan hasil pemeriksaan glukosa darah pasien. Penting mengetahui dan memahami tahapan Good Laboratory Practice (GLP) yaitu pra examination, examination, dan post examination. Tahap pra examination merupakan tahap penentuan kualitas sampel yang akan digunakan pada tahap-tahap selanjutnya (Mengko, 2013). Rata-rata tingkat kesalahan laboratorium yaitu tahap pra examination memberikan kontribusi sebesar 46-77,1\%, examination $7-13 \%$, dan post examination 18,5-47\% (Indyanty et al., 2015). Tujuan penelitian ini adalah melakukan evaluasi analitik nilai glukosa serum dan plasma EDTA terhadap whole blood yang diperiksa menggunakan POCT metode glucose dehydrogenase.

\section{METODE}

Jenis penelitian yang digunakan adalah metode analitik dengan rancangan komparatif. Variabel independen atau variabel bebas dalam penelitian ini adalah glukosa serum dan plasma EDTA. Variabel dependen atau variabel terikat dalam penelitian ini adalah glukosa whole blood. Sampel dalam penelitian ini adalah mahasiswa Jurusan Teknologi Laboratorium Medis Poltekkes Kemenkes Kaltim yaitu sebanyak 40 orang. Minimum sampel pada penelitian analitik adalah 40 spesimen dan dilakukan secara duplo (Westgard, 2019).

Evaluasi analitik ditentukan dengan menilai presisi dan akurasi glukosa serum dan plasma EDTA terhadap whole blood sebagai spesimen standar. Evaluasi analitik digunakan untuk menentukan ada tidaknya perbedaan hasil pemeriksaan jika dilihat dari aspek klinis dengan menentukan Total Error (TE) yang dibandingkan dengan Total Error Allowable (TEa) dan secara statistik dengan uji $\mathrm{T}$ tidak berpasangan (Independent T-test). Apabila data terdistribusi normal maka menggunakan statistik parametrik yaitu uji $\mathrm{T}$ tidak berpasangan dan jika tidak terdistribusi normal maka menggunakan statistik non parametrik yaitu One-Sampel Kolmogorov-Smirnov Test. 
Kesuma, S., dkk: Evaluasi Analitik POCT Metode Glucose Dehydrogenase Parameter Glukosa Pada Spesimen Serum dan Plasma EDTA

HASIL

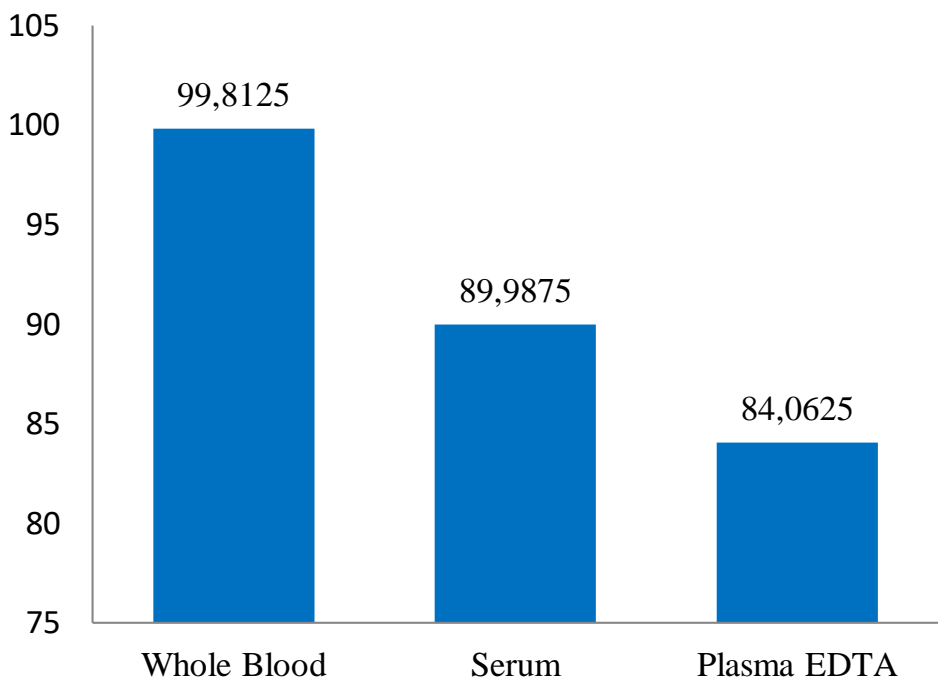

Sumber: Data Primer 2019

Gambar 1. Rata-rata Nilai Glukosa Darah Mahasiswa Jurusan Teknologi Laboratorium Medis

Rata-rata nilai glukosa whole blood sebesar $99,8125 \mathrm{mg} / \mathrm{dl}$, rata-rata nilai glukosa serum 89,9875 $\mathrm{mg} / \mathrm{dl}$, dan rata-rata nilai glukosa plasma EDTA sebesar 84,0625 mg/dl.

Tabel 1. Total Error Nilai Glukosa Serum terhadap Whole Blood

\begin{tabular}{lrrrrr}
\hline & $\begin{array}{l}\text { Presisi } \\
(\mathrm{CV} \%)\end{array}$ & $\begin{array}{c}\text { Akurasi } \\
(\mathrm{d} \%)\end{array}$ & $\begin{array}{c}\text { Total Error } \\
(\mathrm{TE} \%)\end{array}$ & $\begin{array}{l}\text { Total Error } \\
\text { Allowable } \\
(\mathrm{TEa} \%)\end{array}$ \\
\hline Hasil & 3,3 & $-9,8$ & 16,4 & 10 \\
\hline
\end{tabular}

Sumber: Data Primer 2019

Berdasarkan Tabel 1, nilai glukosa serum terhadap whole blood yang diperiksa menggunakan POCT metode Glucose
Dehydrogenase diperoleh presisi 3,3\%, akurasi $-9,8 \%$ dan total error $16,4 \%$. Total error allowable pemeriksaan glukosa adalah $10 \%$. 
Kesuma, S., dkk: Evaluasi Analitik POCT Metode Glucose Dehydrogenase Parameter Glukosa Pada Spesimen Serum dan Plasma EDTA

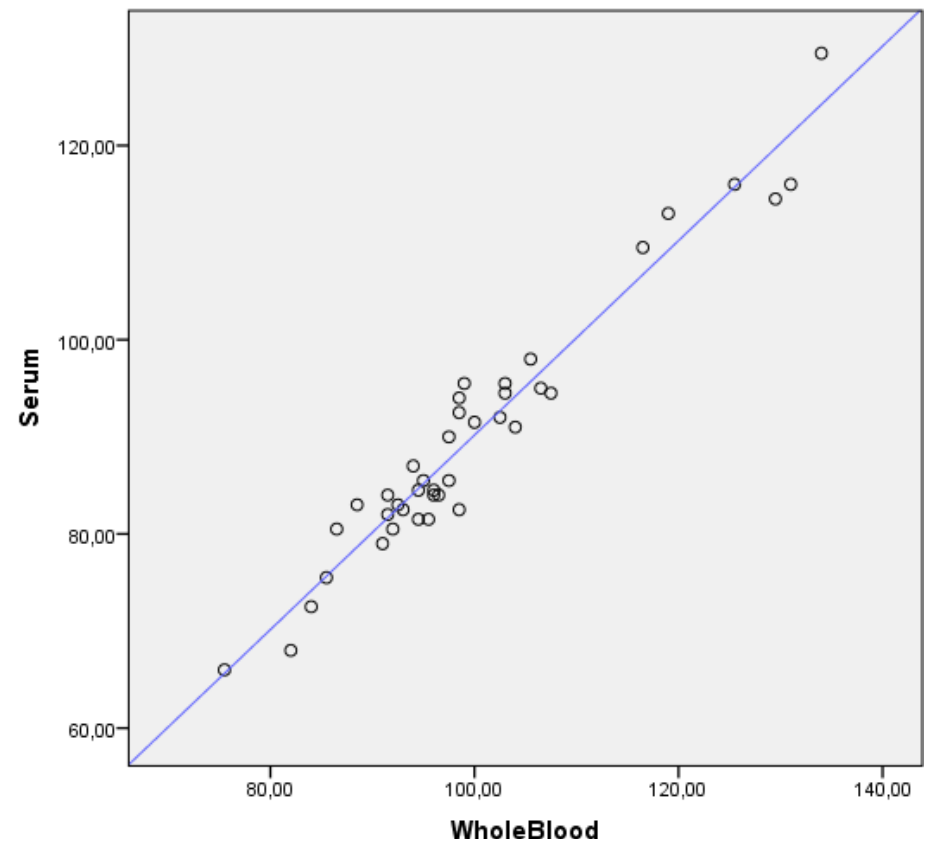

Sumber: Data Primer 2019

Gambar 2. Linearitas Nilai Glukosa Serum terhadap Whole Blood

Berdasarkan Gambar 2 diperoleh

persamaan garis $\mathrm{y}=1,0015 \mathrm{x}-9,9776$, dengan

gradien linearitas $R^{2}=0,9453$ dan $R=0,9722$.

Tabel 2. Hasil Uji Normalitas Data

\begin{tabular}{lr}
\hline & \multicolumn{2}{c}{ Signifikansi } \\
\hline Sumber: Data Primer 2019 & .980 \\
\hline
\end{tabular}

Berdasarkan Tabel 2, hasil uji 0,980. Data dinyatakan terdistribusi normal normalitas data diperoleh nilai signifikansi (p) karena nilai signifikansi (p) $>0,05$. Analisis glukosa serum terhadap whole blood adalah data dilanjutkan dengan uji Independent T-test.

Tabel 3. Hasil Uji Independent T-test

\begin{tabular}{lr}
\hline & \multicolumn{1}{c}{ Signifikansi } \\
\hline Nilai Glukosa Serum terhadap Whole Blood & .001 \\
\hline Sumer: Data Primer 2019
\end{tabular}

Berdasarkan Tabel 3, hasil uji Independent T-test dengan interval kepercayaan 95\% diperoleh nilai signifikansi

$(p)=0,001(p<0,05)$ yang artinya terdapat 
Kesuma, S., dkk: Evaluasi Analitik POCT Metode Glucose Dehydrogenase Parameter Glukosa Pada Spesimen Serum dan Plasma EDTA

perbedaan yang berarti antara nilai glukosa menggunakan POCT metode Glucose serum terhadap whole blood yang diperiksa Dehydrogenase.

Tabel 4. Total Error Glukosa Plasma EDTA terhadap Whole Blood

\begin{tabular}{lccrrr}
\hline & $\begin{array}{c}\text { Presisi } \\
(\mathrm{CV} \%)\end{array}$ & $\begin{array}{c}\text { Akurasi } \\
(\mathrm{d} \%)\end{array}$ & $\begin{array}{c}\text { Total Error } \\
(\mathrm{TE} \%)\end{array}$ & $\begin{array}{c}\text { Total Error } \\
\text { Allowable } \\
(\mathrm{TEa} \%)\end{array}$ \\
\hline Hasil & 3,5 & $-15,8$ & 22,7 & 10 \\
\hline
\end{tabular}

Sumber: Data Primer 2019

Berdasarkan Tabel 4, nilai glukosa plasma EDTA terhadap whole blood yang diperiksa menggunakan POCT metode Glucose Dehydrogenase diperoleh presisi

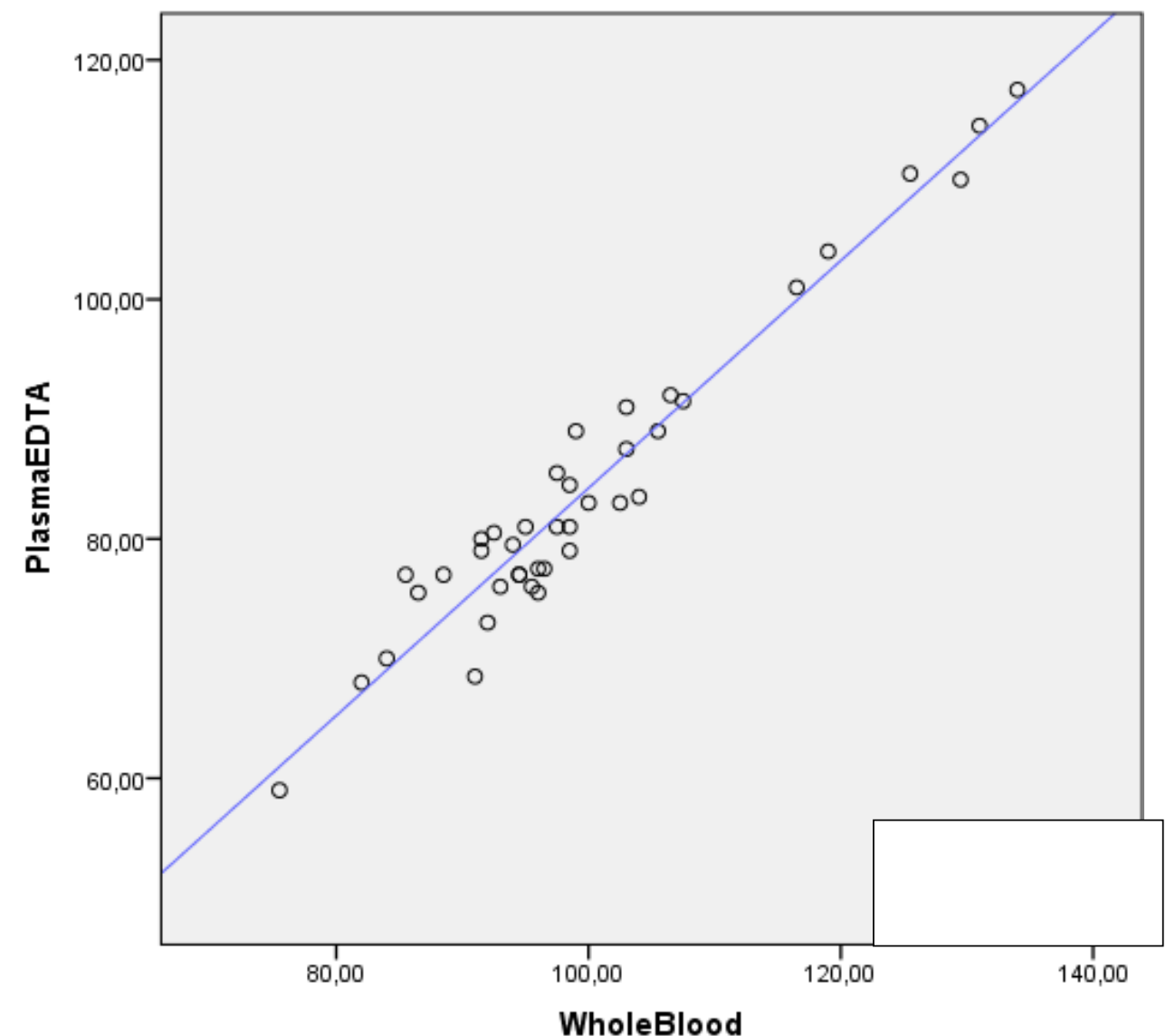

Sumber: Data Primer 2019

Gambar 3. Linearitas Nilai Glukosa Plasma EDTA terhadap Whole Blood

Total error allowable pemeriksaan glukosa adalah $10 \%$.

$3,5 \%$, akurasi $-15,8 \%$ dan total error $22,7 \%$.

WholeBlood

Meditory | ISSN Online : 2549-1520, ISSN Cetak : 2338 - 1159, Vol. 9, No. 1, Juni 2021

Hlm. 26 - 36, http://ejournal.poltekkes-denpasar.ac.id/index.php/M 
Kesuma, S., dkk: Evaluasi Analitik POCT Metode Glucose Dehydrogenase Parameter Glukosa Pada Spesimen Serum dan Plasma EDTA

Berdasarkan Gambar 3 diperoleh gradien linearitas $\mathrm{R}^{2}=0,9401$.

persamaan garis $\mathrm{y}=0,9499 \mathrm{x}-10,746$ dan

Tabel 5. Hasil Uji Normalitas Data

\begin{tabular}{lr}
\hline & Signifikansi \\
\hline Nilai Glukosa Plasma EDTA terhadap Whole Blood & .982 \\
\hline Sumber: Data Primer 2019 &
\end{tabular}

Berdasarkan Tabel 5, hasil uji terdistribusi normal karena nilai signifikansi normalitas data diperoleh nilai signifikansi (p) (p) $>0,05$. Analisis data dilanjutkan dengan uji glukosa serum dan plasma EDTA terhadap Independent T-test. whole blood adalah 0,982 . Data dinyatakan

Tabel 6. Hasil Uji Independent T-test

\begin{tabular}{lr}
\hline & \multicolumn{1}{c}{ Signifikansi } \\
\hline Nilai Glukosa Plasma EDTA terhadap Whole Blood & .000 \\
\hline Sumber: Data Primer 2019 &
\end{tabular}

Berdasarkan Tabel 6 hasil uji Independent T-test dengan interval kepercayaan $95 \%$ diperoleh nilai signifikansi $(p)=0,000(p<0,05)$ yang artinya terdapat perbedaan yang berarti antara nilai glukosa plasma EDTA terhadap whole blood yang diperiksa menggunakan POCT metode Glucose Dehydrogenase.

\section{PEMBAHASAN}

Berdasarkan hasil analisa data nilai glukosa serum dan plasma EDTA terhadap whole blood pada 40 responden yang diperiksa menggunakan POCT metode Glucose Dehydrogenase secara duplo, diperoleh hasil bahwa nilai glukosa darah pada sampel spesimen serum dan plasma EDTA cenderung lebih rendah dari sampel whole blood (Subiyono et al., 2016).

Nilai glukosa plasma EDTA cenderung lebih rendah dibandingkan nilai serum karena adanya Tripotasium EDTA (K3EDTA) bersifat dilusi atau mengencerkan darah. Garam oksalat yang ada pada antikoagulan EDTA dapat mengecilkan sel darah merah yang menyebabkan air di dalam sel keluar sehingga terjadi pengenceran (Permadi, 2018). Jika volume darah lebih banyak dari volume EDTA, maka akan menyebabkan koagulasi. Jika volume darah lebih sedikit dari volume EDTA, maka akan menyebabkan eritrosit krenasi dan trombosit membesar. Dipotasium EDTA (K2EDTA) lebih dianjurkan dibandingkan K3EDTA oleh The International 
Kesuma, S., dkk: Evaluasi Analitik POCT Metode Glucose Dehydrogenase Parameter Glukosa Pada Spesimen Serum dan Plasma EDTA

Counsil For Standardization in Hematology

(ICSH) (Subiyono et al., 2016).

Hasil penelitian ini sejalan dengan hasil penelitian sebelumnya yaitu mengenai "Gambaran Nilai Trigliserida pada Sampel Serum dan Plasma EDTA" bahwa nilai trigliserida serum lebih tinggi dibandingkan dengan nilai trigliserida plasma EDTA. Begitupun dengan hasil penelitian lain tentang "Perbedaan Nilai Glukosa Darah pada Plasma EDTA dan Serum dengan Penundaan Pemeriksaan" bahwa nilai glukosa serum lebih tinggi dibandingkan dengan nilai glukosa plasma EDTA, dengan rata-rata nilai glukosa serum sebesar 92,20 mg/dl dan nilai glukosa plasma EDTA sebesar 89,18 mg/dl. Hal tersebut disebabkan oleh garam oksalat yang ada pada antikoagulan EDTA dapat mengecilkan sel darah merah dan menyebabkan air di dalam sel keluar sehingga terjadi pengenceran pada plasma itu sendiri (Hardisari \& Koiriyah, 2016; Apriani \& Alfita, 2018).

Presisi nilai glukosa serum terhadap whole blood yaitu 3,3\% dan presisi nilai glukosa plasma EDTA terhadap whole blood yaitu $3,5 \%$. Presisi pemeriksaan ini dinyatakan baik dengan acuan menurut American Diabetes Association (ADA) bahwa koefisien variasi glukometer atau POCT harus kurang dari 5\%. POCT untuk memonitoring glukosa darah harus mempunyai metode dengan presisi yang baik, semakin kecil nilai koefisien variasi semakin teliti metode tersebut (Keputusan Menteri Kesehatan Republik Indonesia, 2010). Akurasi nilai glukosa serum terhadap whole blood yaitu $-9,8 \%$ dan akurasi nilai glukosa plasma EDTA terhadap whole blood yaitu $15,8 \%$. Akurasi pemeriksaan ini bernilai negatif yang menunjukkan nilai yang cenderung lebih rendah dari nilai glukosa standar. Hal ini menjawab gambar 1 bahwa penggunaan sampel specimen serum dan plasma EDTA pada pemeriksaan glukosa menggunakan POCT metode glucose dehydrogenase cenderung lebih rendah jika dibandingkan dengan nilai glukosa dengan sampel whole blood (Peraturan Menteri Kesehatan Republik Indonesia, 2013).

Total Error allowable (TEa) merupakan target Statistical Quality Control (SQC) yang mendeteksi kesalahan sistematik dan kesalahan acak. Artinya perhitungan Total Error (TE) tidak boleh melebihi TEa. Batasan TEa dapat dilihat dari konsensus yang diterbitkan organisasi laboratorium seperti Clinical Laboratory Improvement Amandement (CLIA) atau badan profesional lainnya. Adapun TEa pemeriksaan glukosa darah yaitu $10 \%$, sedangkan TE pada penelitian ini sebesar $16,4 \%$ dan $22,7 \%$. yang artinya terdapat perbedaan secara klinis terhadap ketiga sampel (Hens et al., 2014; Karkalousos \& Evangelopoulos, 2010; Harr et al., 2013).

Berdasarkan gambar 2 pada nilai konstanta -9,9776 menunjukkan bahwa nilai glukosa serum memiliki nilai yang lebih kecil sejumlah -9,9776 daripada nilai glukosa whole blood. Nilai koefisien 1,0015 menunjukkan bahwa nilai glukosa serum memiliki nilai sebesar 1,0015 kali lebih besar daripada nilai 
Kesuma, S., dkk: Evaluasi Analitik POCT Metode Glucose Dehydrogenase Parameter Glukosa Pada Spesimen Serum dan Plasma EDTA

glukosa whole blood. Nilai korelasi (R) sebesar 0,9722 menunjukkan bahwa nilai glukosa serum dan whole blood memiliki hubungan yang sangat kuat, artinya penurunan nilai glukosa serum diikuti dengan penurunan nilai glukosa whole blood (Kadir, 2016; Nurgiyantoro \& Gunawan, 2017).

Berdasarkan gambar 3 pada nilai konstanta $-10,746$ menunjukkan bahwa nilai glukosa plasma EDTA memiliki nilai yang lebih kecil sejumlah $-10,746$ daripada nilai glukosa whole blood. Nilai koefisien 0,9499 menunjukkan bahwa nilai glukosa plasma EDTA memiliki nilai sebesar 0,9499 kali lebih besar daripada nilai glukosa whole blood. Nilai korelasi (R) sebesar 0,9695 menunjukkan bahwa nilai plasma EDTA dan whole blood memiliki hubungan sangat kuat, artinya penurunan nilai glukosa plasma EDTA diikuti dengan penurunan nilai whole blood (Kadir, 2016; Nurgiyantoro \& Gunawan, 2017)

Adapun faktor interferensi yang dapat menyebabkan kesalahan pembacaan di glukometer atau POCT digolongkan menjadi dua kelompok, yaitu glukosa dan zat pengganggu. Reaksi silang dapat terjadi antara enzim di uji strip dan zat dalam darah yang mirip dengan glukosa seperti maltose, galaktosa dan silosa. Pada metode Glucose Dehydrognenase, faktor yang dapat mempengaruhi nilai glukosa darah adalah bilirubin, hematokrit dan tekanan darah rendah (Astuti, 2012). Hematokrit harus di antara 10 hingga $65 \%$, apabila kondisi hematokrit diatas nilai maksimum dan diikuti tekanan darah rendah maka nilai glukosa darah akan terbaca rendah, sedangkan nilai hematokrit di bawah nilai minimum maka nilai glukosa darah akan terbaca lebih tinggi (Astuti, 2012; Manual Accu-Chek Instant S, 2018)

\section{KESIMPULAN}

Presisi pemeriksaan glukosa menggunakan POCT metode glucose dehydrogenase pada sampel serum dan plasma EDTA tergolong baik. Akurasi pemeriksaan glukosa menggunakan POCT metode glucose dehydrogenase pada sampel serum dan plasma EDTA bernilai negatif yang berarti hasil pemeriksaan cenderung lebih rendah daripada sampel whole blood. Terjadi perbedaan klinis pada nilai glukosa menggunakan sampel serum dan plasma EDTA sehingga penggunaan sampel tersebut tidak layak untuk digunakan untuk tujuan diagnosis menggunakan POCT metode glucose dehydrogenase. Terdapat perbedaaan secara statistik pada glukosa serum dan plasma EDTA terhadap whole blood yang diperiksa menggunakan POCT metode glucose dehydrogenase dengan nilai korelasi (R) pemeriksaan sebesar 0,9722 dan 0,9695.

\section{DAFTAR PUSTAKA}

Apriani, \& Alfita, U. (2018). Perbedaan Kadar Glukosa Darah Pada Plasma EDTA dan Serum Dengan Penundaan Pemeriksaan. Jurnal Vokasi Kesehatan, 4(1), 19-22.

Astuti, G. (2012). Analitik Pemeriksaan Glukosa dengan Glukosameter. Dalam: Pemeriksaan Laboratorium pada Diabetes Mellitus. IIdonesian Journal of Clinical Pathology. www.indonesianjournalofclinicalpatholo gy.org 
Kesuma, S., dkk: Evaluasi Analitik POCT Metode Glucose Dehydrogenase Parameter Glukosa Pada Spesimen Serum dan Plasma EDTA

Aulia, D. (2016). POCT (Point Of Care Testing) Pada Pemeriksaan Glukosa dan Keton Darah. Indonesian Journal of Clinical Pathology. www.indonesianjournalofclinicalpatholo gy.org

Bishop, M. L., Fody, E. P., \& Schoeff, L. E. (2010). Clinical Chemistry: Techniques, Principles, Correlations (6th ed.). Wolters Kluwer Health-LWW.

Depkes RI. (2004). Pedoman Praktek Laboratorium Yang Besar (Good Laboratory Practice) (3rd ed.). Direktorat Jendral Pelayanan Medik Departemen Kesehatan RI.

Hardisari, R., \& Koiriyah, B. (2016). Gambaran Kadar Trigliserida (Metode Gpo-Pap) Pada Sampel Serum dan Plasma EDTA. Jurnal Teknologi Laboratorium, 5, 27-31.

Harr, K., Flatland, B., Nabity, M., \& Freeman, K. (2013). ASVCP Guidlines Allowable Total Error. Quality Assurance and Laboratory Standards Committe, 1-14.

Hens, K., Berth, M., Armbruster, D., \& Westgard, S. (2014). Sigma metrics used to assess analytical quality of clinical chemistry assays: importance of the allowable total error (TEa) target. Clinical Chemistry and Laboratory Medicine, 52(7), 973-980.

Indyanty, E. W., Rasyid, H. Al, \& Thoyib, A. (2015). Pengaruh Pengetahuan, Sikap, dan Perilaku Perawat tentang Flebotomi terhadap Kualitas Spesimen Lboratorium. 1(1).

Kadir. (2016). Statistik Terapan: Konsep, Contoh dan Analisi Data dengan Program SPSS/Lisrel dalam Penelitian. Rajawali Pers.

Karkalousos, P., \& Evangelopoulos, A. (2010). Quality Control in Clinical Laboratory. www.intechopen.com

Kemenkes RI. (2018). Cegah, Cegah, dan
Cegah: Suara Dunia Perangi Diabetes. 13 Desember. p2ptm.kemkes.go.id/kegiatanp2ptm/pusat-/cegah-dan-cegah-suaradunia-perangi-diabetes

Keputusan Menteri Kesehatan Republik Indonesia, (2010). https://patologiklinik.com

Manual Accu-Chek Instant S. (2018). User's Manual Accu-Chek Instant $S$ Blood Glucose Meter. Roche Diagnostics Australia.

McPherson, R. A., \& Pincus, M. R. (2011). Henry's Clinical and Management by Laboratory Methods (22nd ed.). Elsevier Saunders.

Mengko, R. (2013). Instrumen Laboratorium Klinik. Institut Teknologi Bandung.

Monosik, R., Stred'ansky, M., Luspai, K., Magdolen, P., \& Sturdika, E. (2012). Amperometric glucose biosensor utilizing FAD-dependent glucose dehydrogenase immobilized on nanocomposite electrode. Enzyme and Microbial Technology. https://ncbi.nlm.nih.gov

Nurgiyantoro, B., \& Gunawan, M. (2017). Statistik Terapan Untuk Penelitian Ilmu Sosial: Teori dan Praktik dengan IBM SPSS statistic 21 (7th ed.). Gadjah Mada University Press.

Permadi, D. R. (2018). Perbedaan Antikoagulan K2EDTA dengan K3EDTA Terhadap Nilai Hematokrit Metode Automatic. Universitas Muhammadiyah Semarang.

Peraturan Menteri Kesehatan Republik Indonesia, (2013). labcito.co.id

Rosman, S. (2018). Perbedaan Hasil Pemeriksaan Gula Darah Sewaktu Pada Spesimen Whole Blood Dan Plasma EDTA Menggunakan POCT. Universitas Muhammadiyah Semarang.

Subiyono, Martsiningsih, M. A., \& Gabrela, D. (2016). Gambaran Kadar Glukosa 
Kesuma, S., dkk: Evaluasi Analitik POCT Metode Glucose Dehydrogenase Parameter Glukosa Pada Spesimen Serum dan Plasma EDTA

Darah Metode GOD-PAP ( Glucose Oxsidase - Peroxidase Aminoantypirin ) Sampel Serum dan Plasma EDTA ( Ethylen Diamin Terta Acetat ). 5(1), 4548. www.teknolabjournal.com

Sugiyono. (2007). Statistik Untuk Penelitian. Alfabeta.
Westgard, J. O. (2019). Basic Method Validation: The Comparison of Methods Experiment.

https://www.westgard.com/lesson23.htm

Widagdho. (2013). Point of Care Testing (POCT) - Kimia Darah. https://www.mltunite.com 